\title{
Kepribadian, Motivasi, Dukungan Keluarga dan Pendidikan terhadap Minat Berwirausaha Mahasiswa Jurusan Akuntansi
}

\author{
Cokorda Bagus Wiadnyana Putra ${ }^{1}$ \\ Fakultas Ekonomi dan Bisnis \\ Universitas Udayana, Indonesia
}

\author{
I Wayan Ramantha ${ }^{2}$ \\ Fakultas Ekonomi dan Bisnis \\ Universitas Udayana, Indonesia
}

\begin{abstract}
Surel : cokbagus111@gmail.com
\section{ABSTRAK}

Penelitian ini dilakukan untuk mengetahui pengaruh kepribadian, motivasi yang terdiri dari motivasi karir dan ekonomi, dukungan keluarga, pendidikan akuntansi dan pendidikan kewirausahaan terhadap minat berwirausaha mahasiswa jurusan akuntansi reguler Fakultas Ekonomi dan Bisnis Universitas Udayana. Populasi dalam penelitian ini adalah mahasiswa jurusan akuntansi regular angkatan 2016. Metode Penentuan sampel menggunakan teknik sampling jenuh. Sampel dalam penelitian berjumlah 120 orang. Metode pengumpulan data adalah metode survei dengan kuesioner. Teknik analisis data adalah uji asumsi klasik dan analisis regresi linear berganda. Berdasarkan hasil analisis ditemukan bahwa kepribadian, motivasi yang meliputi motivasi karir dan ekonomi, dukungan keluarga, pendidikan akuntansi, serta pendidikan kewirausahaan berpengaruh positif terhadap minat berwirausaha mahasiswa jurusan akuntansi regular Bukit.
\end{abstract}

Kata Kunci: Kepribadian; Motivasi; Dukungan; Pendidikan; Berwirausaha.

\section{Personality, Motivation, Family Support and Education on Entrepreneurial Interest in Students of the Bukit Regular Accounting Department}

\begin{abstract}
This research was conducted to determine the influence of personality, motivation consisting of career and economic motivation, family support, accounting education and entrepreneurship education on the interest in entrepreneurship in regular accounting students majoring in the Faculty of Economics and Business, Udayana University. The population in this study were students majoring in regular accounting, class 2016. Methods of determining the sample using saturated sampling technique. The sample in this study amounted to 120 people. The data collection method is a survey method with a questionnaire. The data analysis technique is the classical assumption test and multiple linear regression analysis. Based on the results of the analysis, it was found that personality, motivation which includes career and economic motivation, family support, accounting education, and entrepreneurship education have a positive effect on students' interest in entrepreneurship in the Bukit regular accounting major.
\end{abstract}

Keywords: Personality; Motivation; Endorsement; Education; Entrepreneurship.

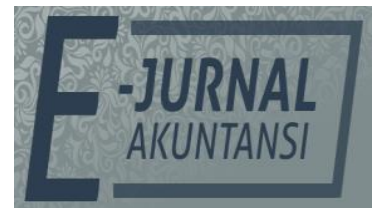

e-ISSN 2302-8556

Vol. 31 No. 2

Denpasar, Februari 2021

Hal. 324-336

DOI:

10.24843/EJA.2021.v31.i02.p05

PENGUTIPAN:

Putra, C.B.W., \& Ramantha, I

W. (2021). Kepribadian,

Motivasi, Dukungan

Keluarga dan Pendidikan terhadap Minat

Berwirausaha Mahasiswa Jurusan Akuntansi. E-Jurnal Akuntansi, 31(2), 324-336

RIWAYAT ARTIKEL:

Artikel Masuk:

3 Oktober 2020

Artikel Diterima:

8 Februari 2021

Artikel dapat diakses : https://ojs.unud.ac.id/index.php/Akuntansi/index 


\section{PENDAHULUAN}

Menjadi seorang pengusaha, bekerja sendiri, mengatur, mengelola dan bertanggung jawab untuk bisnis, menawarkan tantangan pribadi yang besar karena kebanyakan individu lebih suka menjadi karyawan dan bekerja untuk orang lain. Pengusaha harus menerima resiko keuangan pribadi dengan memiliki bisnis namun juga memiliki manfaat langsung dari potensi keberhasilan bisnis. Menjadi seorang pengusaha sering dipandang sebagai pilihan karir pertentangan dimana satu dihadapkan dengan kehidupan dan pekerjaan situasi sehari-hari yang penuh dengan peningkatan ketidakpastian, hambatan, kegagalan dan frustasi yang berhubungan dengan proses penciptaan perusahaan baru (Campbell, 1992).

Kurangnya ketertarikan mahasiswa terhadap bidang kewirausahaan dan menganggap berwirausaha lebih berat dibandingkan bekerja sebagai pegawai pada perusahaan yang sudah ada. Kepribadian seseorang dapat mempengaruhi niat atau tidaknya ia berwirausaha, seseorang dalam memilih karir pada dasarnya berkaitan dengan kepribadian mereka, termasuk menjadi wirausaha. Menurut Anogara (2009) berpendapat bahwa kepribadian seseorang mempengaruhi dirinya dalam memilih pekerjaan. Rendahnya wirausaha muda yang muncul sehingga perlu ditumbuhkan minat untuk menjadi wirausaha pada seorang mahasiswa.

Selain rendahnya minat berwirausaha mahasiswa adapun permasalahan yang sampai saat ini belum bisa diatasi oleh pemerintah tingkat nasional pada umumnya dan tingkat daerah pada khususnya adalah pengangguran. Pengangguran terjadi karena tingginya tingkat perubahan angkatan kerja yang tidak diimbangi dengan adanya lapangan pekerjaan yang cukup luas serta kurangnya penyerapan tenaga kerja. Hal ini disebabkan karena rendahnya tingkat pertumbuhan penciptaan lapangan kerja untuk menampung tenaga kerja yang siap bekerja. Kondisi pengangguran yang tinggi mengakibatkan pemborosan sumber daya dan potensi yang ada, menjadi beban keluarga dan masyarakat, sumber utama kemiskinan dan dapat mendorong seseorang untuk melakukan kriminalitas yang akan menghambat pembangunan dalam jangka panjang. Tingginya tingkat pengangguran di suatu negara memperlihatkan bahwa kesejahteraan masyarakat pada negara tersebut sangat rendah, begitu juga sebaliknya ketika tingkat pengangguran di suatu negara rendah, itu artinya kesejahteraan masyarakat pada negara tersebut sangat tinggi.

Pengangguran lulusan strata 1 (S1) dari berbagai jurusan yang cukup banyak mencerminkan bahwa dengan mendapatkan gelar lulusan strata 1 (S1) tidak menjamin seseorang akan mendapatkan pekerjaan yang diharapkan. Sehingga solusi untuk mengatasi pengangguran adalah dengan berwirausaha. Berwirausaha merupakan suatu kemampuan untuk mengelola sesuatu yang ada dalam diri untuk ditingkatkan agar lebih optimal sehingga bisa meningkatkan taraf hidup di masa mendatang. Menurut Jailani \& Sudarma (2017), mengemukakan bahwa "minat untuk berwirausaha sangatlah penting ditanamkan di universitas yang saat ini menjadi tingkat pengangguran tertinggi, supaya setelah lulus nanti tidak hanya mencari pekerjaan saja tetapi menciptakan lapangan pekerjaan sendiri". Perlunya arahan atau dukungan 
untuk mahasiswa tidak hanya berorientasi sebagai pencari kerja saja, namun juga dapat menciptakan lapangan pekerjaan bagi orang lain.

Sebagai mahasiswa akuntansi seharusnya dapat menyelesaikan masalah tersebut. Selain sebagai tenaga akuntansi divisi keuangan atau finance pada sebuah perusahaan, mahasiswa akuntansi juga dapat berkarir sebagai entrepreneur. Lulusan akuntansi memiliki potensi besar untuk membuka lapangan kerja untuk banyak orang dengan cara berwirausaha. Saat kuliah, mahasiswa jurusan akuntansi selalu diberikan banyak mata kuliah tentang pengembangan bisnis seperti pengantar bisnis, manajemen dan komunikasi bisnis, strategi menjalankan bisnis, dan lain sebagainya. Mata kuliah tersebutlah yang dapat menjadi bekal untuk mulai membuka bisnis baru.

Institusi pendidikan mempunyai pengaruh besar terhadap perkembangan karir seseorang wirausaha. Sebagai sebuah pendidikan kewirausahaan, berwirausaha dapat memberikan kontribusi positif untuk mahasiswa yang ingin mengembangkan kemampuan dibidang wirausaha. Motivasi ekonomi merupakan suatu kondisi atau kecenderungan yang menggerakkan seseorang untuk berusaha mendapatkan dan mengatur harta baik materil maupun non materil dalam rangka memenuhi kebutuhan hidup seseorang.

Wirausahawan harus menentukan jumlah modal yang diperlukan dalam sebuah usaha, seorang wirausahawan harus menentukan jumlah minimum dari masing-masing sumber daya yang diperlukan. Ketersediaan informasi usaha merupakan faktor yang penting dalam berwirausaha, mendorong keinginan seseorang dalam membuka usaha baru dan faktor kritikal bagi pertumbuhan dan kelangsungan usaha (Indarti \& Rostiani, 2008).

Keluarga menjadi tempat interaksi pertama yang dimiliki oleh anak yang terdiri dari ayah, ibu, saudara dan anggota keluarga lainnya. Menurut Boz \& Ergeneli (2014) mengungkapkan bahwa keluarga memiliki peran yang berdampak penting pada keyakinan, harapan dan rencana karier seorang individu di masa depan kelak. Anggota keluarga memiliki peran yang penting dalam memberikan inspirasi dan dukungan antar anggota keluarga satu dengan lainnya. Menurut Trisnawati (2017) mengungkapkan bahwa melalui keluarga, pola pikir kewirausahaan terbentuk, niat berwirausaha tumbuh dan berkembang dengan baik pada seseorang yang hidup dan tumbuh di lingkungan keluarga wirausahawan. Sikap dan peran anggota keluarga dapat mempengaruhi tindakan dalam keputusan yang diambil oleh anak, khususnya dalam memilih karir yang dipilih.

Keluarga memiliki salah satu peran penting dalam diri individu yang dapat mengarahkan kecenderungan untuk berwirausaha. Menurut Marini (2014), berpendapat bahwa dukungan untuk berwirausaha dapat berupa dukungan moril seperti kesempatan, kepercayaan, pemberian ide atau dukungan materiil dengan memberikan modal, penyediaan alat atau perlengkapan usaha dan lokasi usaha. Lingkungan keluarga yang kondusif akan semakin meyakinkan dan mendorong niat individu dalam berwirausaha. Hambatan untuk berwirausaha pun dapat muncul apabila anggota keluarga tidak memberi dukungan kepada individu, melainkan memberi larangan dan 
ketidak persetujuan. Tanpa adanya dukungan keluarga, seseorang tidak mendapat bantuan yang dibutuhkan melalui keberadaan sebuah keluarga.

Dukungan dalam keluarga dapat secara emosional, pemberian informasiinformasi yang berguna, pemberian penghargaan dan dukungan instrumental atau finansial (Periera et al., 2017). Melalui dukungan-dukungan yang diberikan keluarga, akan memberikan perasaan nyaman dan perasaan bahwa anggota keluarga saling mempedulikan satu dengan yang lainnya. Penelitian yang dilakukan oleh Periera et al. (2017) mengungkapkan bahwa dukungan keluarga dapat menentukan tinggi rendahnya niat individu dalam melakukan wirausaha. Individu yang memiliki niat untuk berwirausaha, pasti memerlukan restu dan dukungan dari keluarga sebagai kekuatan, keberanian dan penyemangat untuk melaksanakannya.

Peran pendidikan akuntansi dalam berwirausaha atau bisnis adalah akuntansi memberikan informasi untuk digunakan oleh manajer dalam menjalankan operasi perusahaan. Akuntansi juga memberikan informasi untuk pihk-pihak lain yang berkepentingan dalam menilai kinerja dan kondisi ekonomi perusahaan (Reeve et al., 2009). Menurut Irfani \& Dahria (2009), peran akuntansi sebagai sumber informasi utama untuk pengambilan keputusan perusahaan. Informasi-informasi tersebut dianalisis dan pada akhirnya digunakan sebagai dasar untuk pengambilan keputusan.

Kepribadian merupakan sifat khas yang dimiliki seseorang yang membedakan dengan orang lain. Dalam pemilihan karir sebagai wirausaha kepribadian akan memainkan peranan penting. Seseorang yang memiliki kepribadian yang tangguh, tentu akan berani untuk terjun dalam dunia wirausaha. Begitu pula sebaliknya, seseorang yang cenderung untuk tidak mau lepas dari zona nyaman maka akan sulit untuk melakukan perubahan dengan berwirausaha. Menjadi seorang wirausaha membutuhkan kepribadian yang kuat, karena akan dihadapkan pada berbagai persoalan di dunia usaha. Kepribadian kuat tersebut meliputi rasa percaya diri, berani dalam mengambil risiko, memiliki jiwa pemimpin dan berorientasi ke depan. Seseorang yang memiliki ciri-ciri atau watak yang disebutkan di atas cenderung untuk berani dalam terjun ke dunia wirausaha. Hal ini konsisten dengan hasil penelitian Aprilianty (2012), Indriyani (2019), Baskara (2018) dan penelitian lainnya yang menyatakan bahwa kepribadian berpengaruh tinggi terhadap minat berwirausaha.

$\mathrm{H}_{1}$ : Kepribadian berpengaruh positif terhadap minat berwirausaha Mahasiswa jurusan akuntansi reguler bukit.

Teori harapan Victor Vroom menyatakan bahwa individu akan termotivasi untuk mengeluarkan tingkat usaha yang tinggi ketika mereka yakin bahwa usaha tersebut akan menghasilkan penilaian kinerja yang baik, dan penilaian kinerja yang baik akan menghasilkan penghargaan organisasional seperti kenaikan imbalan kerja atau promosi jabatan (Robbins \& Judge, 2015). Motivasi karir merupakan dorongan yang timbul dalam diri seseorang untuk meningkatkan kemampuan pribadinya dalam rangka mencapai kedudukan, jabatan, atau karir yang lebih baik dari sebelumnya (Rahadian, 2008). Hal ini konsisten dengan hasil penelitian Kurniawan (2014), Salindri (2014), Dewi (2018) 
dan penelitian lainnya yang menyatakan bahwa pengaruh motivasi karir berpengaruh tinggi terhadap minat berwirausaha.

$\mathrm{H}_{2}$ : Motivasi karir berpengaruh positif terhadap minat berwirausaha mahasiswa jurusan akuntansi reguler bukit.

Penghargaan finansial merupakan salah satu bentuk system pengendalian manajmen. Untuk memastikan bahwa segenap elemen karyawan dapat mengarahkan tindakannya terhadap pencapaian tujuan perusahaan, maka manajemen memberikan balas jasa atau reward dalam berbagai bentuk, termasuk didalamnya financial reward (Apriantoni, 2011). Secara umum penghargaan finansial terdiri atas penghargaan langsung (Upah dasar atau gaji pokok, gaji dari lembur, pembagian dari laba) dan tidak langsung (asuransi, tunjangan biaya sakit, program pensiun). Hal ini didukung oleh penelitian Suharti (2011), Fahriani (2012), Utami \& Sari (2017) dan penelitian lainnya yang menyatakan bahwa pengaruh motivasi ekonomi berpengaruh tinggi terhadap minat berwirausaha.

$\mathrm{H}_{3}$ : Motivasi ekonomi berpengaruh positif terhadap minat berwirausaha mahasiswa jurusan Akuntansi Reguler Bukit.

Hasil penelitian yang dilakukan Fradani (2016) menunjukkan bahwa dukungan dari keluarga memiliki pengaruh positif pada niat berwirausaha seorang anak. Begitu pula dengan penelitian yang dilakukan Herdijono et al. (2017) yang menunjukan bahwa keluarga memiliki pengaruh positif pada niat berwirausaha dalam diri seorang anak. Menurut Alma (2013) menjadi seorang wirausahawan merupakan hasil dari dukungan orangtua atau keluarga karena dengan dukungan tersebut dapat memberikan dorongan bagi seorang anak. Pekerjaan orang-tua yang berwirausaha juga dapat memicu seorang anak untuk berwirausaha dengan mengikuti jejak orangtua untuk menentukan karir atau pekerjaan yang akan diambil kelak.

Penelitian yang dilakukan Periera et al. (2017) juga menyatakan bahwa dukungan lingkungan keluarga berpengaruh positif terhadap niat berwirusaha seseorang. Semakin tinggi dukungan yang diberikan, maka akan semakin mendorong anak untuk menjadi wirausaha dan begitu juga sebaliknya, Shen et al. (2017) juga mengungkapkan penelitiannya yang menunjukan bahwa dukungan keluarga berpengaruh positif terhadap keinginan dan kelayakan seseorang untuk memulai usaha. Shen et al. (2017) mengunkapkan bahwa keluarga dikonseptualisasikan dan dinilai sebagai konteks niat berwirausaha individu, dukungan yang dirasakan dari keluarga dapat memainkan peran penting pada perilaku individu dan pilihan hidup.

$\mathrm{H}_{4}$ : Dukungan keluarga berpengaruh positif terhadap minat berwirausaha mahasiswa jurusan Akuntansi Reguler Bukit.

Peran pendidikan akuntansi dalam berwirausaha atau bisnis adalah akuntansi memberikan informasi untuk digunakan oleh manajer dalam menjalankan operasi perusahaan. Akuntansi juga memberikan informasi untuk pihak-pihak yang berkepentingan dalam menilai kinerja dan kondisi ekonomi perusahaan (Reeve et al., 2009). Menurut Irfani \& Dahria (2009), peran akuntansi sebagai sumber informasi utama untuk pengambilan keputusan perusahaan. Informasi-informasi tersebut dianalisis dan pada akhirnya dipakai sebagai dasar untuk pengambilan keputusan. Hal ini didukung oleh penelitian Suharti (2011), 
Kusumastuti \& Waluyo (2013) , Utami \& Sari (2017) dan penelitian lainnya yang menyatakan bahwa pengaruh pendidikan akuntansi berpengaruh tinggi terhadap minat berwirausaha.

$\mathrm{H}_{5}$ : Pendidikan Akuntansi berpengaruh positif terhadap minat berwirausaha mahasiswa jurusan Akuntansi Reguler Bukit.

Pendidikan dan pengetahuan memiliki peranan yang sangat penting dalam memotivasi atau menumbuhkan minat mahasiswa untuk berwirausaha. Mahasiswa jurusan Akuntansi Reguler Bukit selama menempuh perkuliahan di Fakultas Ekonomi dan Bisnis Universitas Udayana diberikan matakuliah kewirausahaan yang dapat memotivasi mahasiswa jurusan Akuntansi Reguler Bukit untuk semakin meningkatkan minat berwirausaha. Hal ini didukung oleh penelitian Lestari (2012), Utami \& Sari (2017), Dewi (2018) dan penelitian lainnya yang menyatakan bahwa pengaruh pendidikan kewirausahaan berpengaruh tinggi terhadap minat berwirausaha.

$\mathrm{H}_{6}$ : Pendidikan kewirausahaan berpengaruh posistif terhadap minat berwirausaha mahasiswa jurusan Akuntansi Reguler Bukit.

\section{METODE PENELITIAN}

Penelitian ini dilakukan pada mahasiswa jurusan akuntansi program reguler angkatan 2016, Fakultas Ekonomi dan Bisnis Universitas Udayana, yang beralamat di Jl. Raya Kampus UNUD No.2013, Jimbaran, Kec. Kuta Selatan, kabupaten Badung. Alasan yang mendasari dipilihnya lokasi ini karena penelitian ini merupakan studi empiris pada mahasiswa jurusan akuntansi program reguler angkatan 2016 yang segala aktivitasnya dilaksanakan di Fakultas Ekonomi dan Bisnis Universitas Udayana.

Populasi pada penelitian ini adalah seluruh mahasiswa jurusan Akuntansi Reguler Bukit angkatan 2016 Fakultas Ekonomi dan Bisnis Universitas Udayana yang berjumlah 179 orang. Alasan yang mendasari dipilihnya mahasiswa jurusan Akuntansi Reguler Bukit angkatan 2016 karena kini berada diakhir masa perkuliahan sehingga diharapkan telah memiliki perencanaan dalam melanjutkan pendidikan atau karir. Pengambilan sampel berarti mengambil sebagian saja dari populasi untuk menggambarkan populasi secara keseluruhan atau representatif. Sampel dalam penelitian ini adalah mahasiswa aktif program S1 Akuntansi Bukit angkatan 2016 di Fakultas Ekonomi dan Bisnis Universitas Udayana yang telah memenuhi kriteria penentuan sampel.Metode penentuan sampel yang digunakan dalam penelitian ini adalah metode nonprobability sampling dengan menggunakan teknik purposive sampling. Metode purposive sampling adalah metode pengambilan sampel berdasarkan kriteria-kriteria tertentu yang dianggap dapat mewakili objek yang akan diteliti (relevan) sesuai dengan tujuan penelitian.

Analisis regresi linier berganda dilakukan untuk mengetahui hubungan antar lebih dari dua variabel, yang dalam penelitian ini adalah untuk mengetahui pengaruh kepribadian, motivasi, dukungan keluarga, pendidikan akuntansi dan pendidikan kewirausahaan mahasiswa jurusan Akuntansi Reguler Bukit terhadap minat berwirausaha. Analisis ini dilakukan dengan menggunakan program Statistical Package for Social Sciense (SPSS) dengan tingkat 
signifikansi $5 \%(a=0,05)$. Persamaan analisis regresi linier berganda penelitian ini sebagai berikut.

$$
Y=\alpha+\beta_{1} X_{1}+\beta_{2} X_{2}+\beta_{3} X_{3}+\beta_{4} X_{4}+\beta_{5} X_{5}+\beta_{6} X_{6}+\varepsilon
$$

Keterangan:

$$
\begin{array}{ll}
\mathrm{Y} & =\text { Minat berwirausaha } \\
\mathrm{a} & =\text { Konstanta } \\
\mathrm{X}_{1} & =\text { Kepribadian } \\
\mathrm{X}_{2} & =\text { Motivasi karir } \\
\mathrm{X}_{3} & =\text { Motivasi ekonomi } \\
\mathrm{X}_{4} & =\text { Dukungan keluarga } \\
\mathrm{X}_{5} & =\text { Pendidikan akuntansi } \\
\mathrm{X}_{6} & =\text { Pendidikan kewirausahaan } \\
\beta_{1}-\beta_{6} & =\text { Koefisien regresi variabel independen } \\
\varepsilon & =\text { Standar error }
\end{array}
$$

\begin{tabular}{|c|c|c|c|c|c|}
\hline \multirow[t]{2}{*}{ Model } & \multicolumn{2}{|c|}{$\begin{array}{l}\text { Unstandardized } \\
\text { Coefficients }\end{array}$} & \multirow{2}{*}{$\begin{array}{l}\text { Standardized } \\
\text { Coefficients } \\
\text { Beta }\end{array}$} & \multirow{2}{*}{$\mathrm{T}$} & \multirow{2}{*}{ Sig. } \\
\hline & B & $\begin{array}{l}\text { Std. } \\
\text { Error }\end{array}$ & & & \\
\hline (Constant) & 0,901 & 1,643 & & 0,548 & 0,584 \\
\hline Kepribadian $\left(\mathrm{X}_{1}\right)$ & 0,221 & 0,100 & 0,168 & 2,213 & 0,029 \\
\hline Motivasi karir $\left(X_{2}\right)$ & 0,478 & 0,109 & 0,314 & 4,379 & 0,000 \\
\hline Motivasi Ekonomi $\left(\mathrm{X}_{3}\right)$ & 0,259 & 0,116 & 0,148 & 2,240 & 0,027 \\
\hline Dukungan Keluarga $\left(\mathrm{X}_{4}\right)$ & 0,290 & 0,132 & 0,153 & 2,198 & 0,030 \\
\hline $\begin{array}{l}\text { Pendidikan Akuntansi } \\
\left(\mathrm{X}_{5}\right)\end{array}$ & 0,214 & 0,100 & 0,146 & 2,134 & 0,035 \\
\hline $\begin{array}{l}\text { Pendidikan } \\
\text { Kewirausahaan }\left(X_{6}\right)\end{array}$ & 0,157 & 0,073 & 0,155 & 2,146 & 0,034 \\
\hline Adjusted $\mathrm{R}^{2}$ & & & & & 0,698 \\
\hline $\mathrm{F}$ & & & & & 46,781 \\
\hline Sig. F & & & & & 0,000 \\
\hline
\end{tabular}

\section{HASIL DAN PEMBAHASAN}

Analisis regresi linier berganda dilakukan untuk mengetahui hubungan antar lebih dari dua variabel, dalam penelitian ini adalah untuk mengetahui pengaruh kepribadian, motivasi karir, motivasi ekonomi, dukungan keluarga, pendidikan akuntansi dan pendidikan kewirausahaan mahasiswa jurusan akuntansi reguler bukit terhadap minat berwirausaha. Hasil analisis regresi linier berganda disajikan pada Tabel 1, sebagai berikut.

Tabel 1. Hasil Analisis Regresi Linier Berganda

Sumber: Data Penelitian, 2020

Berdasarkan Tabel 1, diperoleh suatu persamaan regresi sebagai berikut. $\mathrm{Y}=0,901+0,221 \mathrm{X}_{1}+0,478 \mathrm{X}_{2}+0,259 \mathrm{X}_{3}+0,290 \mathrm{X}_{4}+0,214 \mathrm{X}_{5}+0,157 \mathrm{X}_{6}+\varepsilon$

Berdasarkan Tabel 1, menunjukan bahwa nilai Adjusted $R$ Square adalah 0,698 atau $69,8 \%$ ini artinya sebesar $69,8 \%$ variasi minat berwirausaha mahasiswa jurusan akuntansi reguler bukit dipengaruhi oleh kepribadian, motivasi karir, motivasi ekonomi, dukungan keluarga, pendidikan akuntansi, dan pendidikan kewirausahaan. Sedangkan sisanya sebesar 3,02\% dijelaskan oleh faktor lain yang tidak dimasukkan dalam model penelitian ini. Berdasarkan Tabel 1, dapat 
dilihat bahwa nilai signifikansi $\mathrm{F}$ adalah sebesar 0,000 yang lebih kecil dari 5 persen. Hal ini berarti model penelitian layak (fit).

Hasil penelitian berdasarkan uji hipotesis (uji t) pengaruh kepribadian, menunjukkan hasil koefisien regresi 0,221 dengan signifikansi 0,000 < alpha $=0,05$ yang berarti $\mathrm{H}_{1}$ diterima yaitu pengaruh kepribadian memberikan pengaruh yang signifikan pada minat berwirausaha. Koefisien regresi bernilai 0,221 menunjukkan bahwa pengaruh kepribadian berpengaruh positif terhadap minat berwirausaha mahasiswa jurusan akuntansi reguler bukit di Fakultas Ekonomi dan Bisnis Universitas Udayana, sehingga hipotesis pertama diterima. Hal ini berarti sejalan dengan salah satu model dari teori Big Five Personality yaitu conscientiousness bahwa sikap dari individu dalam menjalani kehidupannya, terkait dengan motivasi, keteraturan dan orientasi tujuan masa depan. Hasil penelitian ini berarti bahwa faktor kepribadian mempengaruhi minat seseorang untuk berwirausaha.

Dalam pemilihan karir sebagai wirausaha kepribadian akan memainkan peranan penting. Seseorang yang memiliki kepribadian yang tangguh, tentu akan berani untuk terjun dalam dunia wirausaha. Begitu pula sebaliknya, seseorang yang cenderung untuk tidak mau lepas dari zona nyaman maka akan sulit untuk melakukan perubahan dengan berwirausaha. Menjadi seorang wirausaha membutuhkan kepribadian yang kuat, karena akan dihadapkan pada berbagai persoalan di dunia usaha. Kepribadian kuat tersebut meliputi rasa percaya diri, berani mengambil risiko, memiliki jiwa kepemimpinan dan berorientasi ke masa depan. Seseorang yang memiliki ciri-ciri atau watak yang disebutkan di atas cenderung untuk berani dalam terjun ke dunia wirausaha. Hal ini konsisten dengan hasil penelitian Aprilianty (2012), Indriyani (2019), Baskara (2018) dan penelitian lainnya yang menyatakan bahwa pengaruh kepribadian berpengaruh positif terhadap minat berwirausaha.

Hasil pengujian berdasarkan uji hipotesis (uji t) pengaruh motivasi karir, menunjukkan hasil koefisien regresi 0,478 dengan signifikansi 0,000 < alpha =0,05 yang berarti $\mathrm{H}_{1}$ diterima yaitu pengaruh motivasi karir memberikan pengaruh yang signifikan pada minat berwirausaha. Koefisien regresi bernilai 0,478 menunjukkan bahwa pengaruh motivasi karir berpengaruh positif terhadap minat berwirausaha mahasiswa jurusan akuntansi reguler bukit di Fakultas Ekonomi dan Bisnis Universitas Udayana, sehingga hipotesis kedua diterima. Hal ini berarti sejalan dengan teori Harapan Victor Vroom bahwa individu akan termotivasi untuk mengeluarkan tingkat usaha yang tinggi ketika mereka yakin bahwa usaha tersebut akan menghasilkan penilaiankinerja yang baik. Hasil penelitian ini berarti bahwa semakin tinggi tingkat pengaruh di dalam motivasi karir, maka akan semakin tinggi pula potensi minat berwirausaha.

Teori motivasi menjelaskan dorongan atau kehendak yang menyebabkan seseorang melakukan atau perbuatan untuk mencapai tujuan tertentu. Dengan demikian motivasi karir dapat menumbuhkan minat berwirausaha yaaitu semakin tinggi harapan mahasiswa akan karir yang didapatkan dari berwirausaha maka akan semakin tinggi pula minat mahasiswa untuk berwirausaha. Hal ini konsisten dengan hasil penelitian Kurniawan (2014), Salindri (2014), Dewi (2018) dan penelitian lainnya yang menyatakan bahwa pengaruh motivasi karir berpengaruh positif terhadap minat berwirausaha. 
Hasil penelitian berdasarkan uji hipotesis (uji t) pengaruh motivasi ekonomi, menunjukkan hasil koefisien regresi 0,259 dengan signifikansi 0,000 < alpha $=0,05$ yang berarti $\mathrm{H}_{3}$ diterima yaitu pengaruh motivasi ekonomi memberikan pengaruh yang signifikan pada minat berwirausaha. Koefisien regresi bernilai 0,259 menunjukkan bahwa pengaruh motivasi ekonomi berpengaruh positif terhadap minat berwirausaha mahasiswa jurusan akuntansi reguler bukit di Fakultas Ekonomi dan Bisnis Universitas Udayana, sehingga hipotesis ketiga diterima. Hal ini berarti sejalan dengan teori hierarki kebutuhan Maslow menjelaskan bahwa setiap individu mempunyai beraneka ragam kebutuhan yang dapat mempengaruhi perilaku mereka. Hasil penelitian ini berarti bahwa semakin tinggi tingkat pengaruh di dalam motivasi ekonomi, maka akan semakin tinggi pula potensi minat berwirausaha.

Teori hierarki kebutuhan Maslow menjelaskan bahwa setiap individu mempunyai beraneka ragam kebutuhan yang dapat mempengaruhi perilaku mereka Lubis (2010). Motivasi ekonomi akan timbul karena tuntutan untuk memenuhi kebutuhan fisiologis, kebutuhan akan keamanan, kebutuhan sosial, kebutuhan akan penghargaan dan kebutuhan akan aktualisasi diri. Terutama kebutuhan akan penghargaan yang merupakan kebutuhan akan kedudukan termasuk juga penghargaan finansial. Dengan adanya motivasi ekonomi, seseorang akan melakukan kegiatan ekonomi agar mendapatkan kepuasan materi dan kesejahteraan pribadi maupun keluarga. Hal ini didukung oleh penelitian yang dilakukan Suharti (2011), Fahriani (2012), Utami \& Sari (2017) dan penelitian lainnya yang menyatakan bahwa pengaruh motivasi ekonomi berpengaruh positif terhadap minat berwirausaha.

Hasil penelitian berdasarkan uji hipotesis (uji t) pengaruh dukungan keluarga, menunjukkan hasil koefisien regresi 0,290 dengan signifikansi 0,000< alpha $=0,05$ yang berarti $\mathrm{H}_{4}$ diterima yaitu pengaruh dukungan keluarga memberikan pengaruh yang signifikan pada minat berwirausaha. Koefisien regresi yang bernilai 0,290 menunjukkan bahwa pengaruh dukungan keluarga berpengaruh positif terhadap minat berwirausaha mahasiswa jurusan akuntansi reguler bukit di Fakultas Ekonomi dan Bisnis Universitas Udayana, sehingga hipotesis keempat diterima.

Hal ini berarti sejalan dengan konsep dukungan keluarga menurut Friedman dimana dukungan keluarga merupakan sikap, tindakan dan penerimaan keluarga terhadap anggota keluarga, berupa dukungan informasional, dukungan penilaian, dukungan instrumental dan dukungan emosional. Jadi dukungan keluarga adalah suatu bentuk hubungan interpersonal yang meliputi sikap, tindakan dan penerimaan terhadap anggota keluarga, sehingga anggota keluarga merasa mendapat kepercayaan atau merasa ada yang memperhatikan. Hasil penelitian ini berarti bahwa semakin tinggi tingkat dukungan keluarga yang diberikan, maka semakin tinggi pula minat seseorang untuk berwirausaha. Hal ini didukung oleh penelitian Fradani (2016), Herdijono et al. (2017), Alma (2013) dan penelitian lainnya yang menyatakan bahwa pengaruh dukungan keluarga berpengaruh positif terhadap minat berwirausaha.

Hasil penelitian berdasarkan uji hipotesis (uji t) pengaruh pendidikan akuntansi, menunjukkan hasil koefisien regresi 0,214 dengan signifikansi 0,000< alpha $=0,05$ yang berarti $\mathrm{H}_{5}$ diterima yaitu pengaruh pendidikan akuntansi 
memberikan pengaruh yang signifikan pada minat berwirausaha. Koefisien regresi yang bernilai 0,214 menunjukkan bahwa pengaruh pendidikan akuntansi berpengaruh positif terhadap minat berwirausaha mahasiswa jurusan akuntansi reguler bukit di Fakultas Ekonomi dan Bisnis Universitas Udayana, sehingga hipotesis kelima diterima. Hal ini berarti sejalan dengan Theory of Planned Behaviour (TPB) sikap ataupun perilaku seseorang dipengaruhi oleh keyakinan bahwa perilaku tersebut akan membawa kepada hasil yang diinginkan atau tidak diinginkan.

Dalam pendidikan akuntansi kontrol perilaku itu sendiri juga ditentukan dari perkiraan individu mengenai seberapa sulit atau mudahnya untuk melakukan perilaku yang bersangkutan dan rasa tanggung jawab yang tinggi terhadap perilaku. Hasil penelitian ini berarti semakin tinggi tingkat pengaruh pendidikan akuntansi, maka akan semakin tinggi pula potensi minat berwirausaha.

Peran pendidikan akuntansi dalam berwirausaha atau bisnis adalah akuntansi memberikan informasi untuk digunakan oleh manajer dalam menjalankan operasi perusahaan. Akuntansi juga memberikan informasi untuk pihak-pihak lain yang berkepentingan dalam menilai kinerja dan kondisi ekonomi perusahaan (Reeve et al., 2009). Menurut Irfani \& Dahria (2009), peran akuntansi sebagai sumber informasi utama untuk pengambilan keputusan perusahaan. Hal ini didukung oleh penelitian Suharti (2011), Kusumastuti \& Waluyo (2013), Utami \& Sari (2017) dan penelitian lainnya yang menyatakan bahwa pengaruh pendidikan akuntansi berpengaruh positif terhadap minat berwirausaha.

Hasil penelitian berdasarkan uji hipotesis (uji t) pengaruh pendidikan kewirausahaan, menunjukkan hasil koefisien regresi 0,157 dengan signifikansi $0,000<$ alpha $=0,05$ yang berarti $\mathrm{H}_{6}$ diterima yaitu pengaruh pendidikan kewirausahaan memberikan pengaruh yang signifikan pada minat berwirausaha. Koefisien regresi yang bernilai 0,157 menunjukkan bahwa pengaruh pendidikan kewirausahaan berpengaruh positif terhadap minat berwirausaha mahasiswa jurusan akuntansi reguler bukit di Fakultas Ekonomi dan Bisnis Universitas Udayana, sehingga hipotesis keenam diterima. Hal ini berarti sejalan dengan Theory of Planned Behaviour (TPB) sikap ataupun perilaku seseorang dipengaruhi oleh keyakinan bahwa perilaku tersebut akan membawa kepada hasil yang diinginkan atau tidak diinginkan. Dalam pendidikan kewirausahaan kontrol perilaku itu sendiri juga ditentukan dari perilaku individu mengenai betapa pentingnya pendidikan dalam kewirausahaan dalam mengembangkan bisnis, seberapa sulit atau mudahnya untuk melakukan usaha dan rasa tanggung jawab yang tinggi terhadap perilaku dalam berwirausaha.

Hasil penelitian ini berarti bahwa semakin tinggi tingkat pengaruh pendidikan kewirausahaan, maka akan semakin tingi pula potensi minat berwirausaha. Hal ini didukung oleh penelitian Lestari (2012), Utami \& Sari (2017), Dewi (2018) dan penelitian lainnya yang menyatakan bahwa pengaruh pendidikan kewirausahaan berpengaruh tinggi terhadap minat berwirausaha. 


\section{SIMPULAN}

Pada penelitian ini menunjukkan bahwa kepribadian berpengaruh positif terhadap minat berwirausaha mahasiswa jurusan akuntansi reguler bukit, motivasi karir berpengaruh positif terhadap minat berwirausaha mahasiswa jurusan akuntansi reguler bukit, motivasi ekonomi berpengaruh positif terhadap minat berwirausaha mahasiswa jurusan akuntansi reguler bukit, dukungan keluarga berpengaruh positif terhadap minat berwirausaha mahasiswa jurusan akuntansi reguler bukit, pendidikan akuntansi berpengaruh positif terhadap minat berwirausaha mahasiswa jurusan akuntansi reguler bukit dan pendidikan kewirausahaan berpengaruh positif terhadap minat berwirausaha mahasiswa jurusan akuntansi reguler bukit. Minat berwirausaha mahasiswa jurusan akuntansi reguler bukit semakin meningkat diharapkan dapat menjadi acuan mahasiswa untukmeraih masa depan sehingga solusi untuk mengatasi pengangguran adalah dengan berwirausaha. Perlunya arahan atau dukungan untuk mahasiswa tidak hanya berorientasi sebagai pencari kerja saja, namun juga dapat menciptakan lapangan pekerjaan bagi orang lain. Implikasi teoritis lainnya adalah dapat memberikan acuan atau bahan refrensi bagi akademisi yang sedang melakukan penelitian tentang minat berwirausaha.

Implikasi praktis dalam penelitian ini adalah hasil analisis pengaruh minat mahasiswa jurusan akuntansi reguler bukit yang dilakukan oleh peneliti diharapkan dapat berguna bagi mahasiswa jurusan akuntansi reguler bukit dalam meningkatkan minat berwirausaha. Diharapkan penelitian ini dapat dimanfaatkan oleh mahasiswa dan menjadi acuan untuk masa depan dengan cara berwirausaha dan dapat membantu orang lain dengan cara membuka lapangan pekerjaan.

\section{REFERENSI}

Alma, B. (2013). Aktivitas berwirausaha. Bandung: Alfabeta.

Anogara, P. (2009). Psikologi Kerja. Jakarta: Rineka Cipta.

Apriantoni. (2011). Pengaruh Motivasi, Biaya Pendidikan dan Lama Pendidikan Terhadap Minat Mahasiswa Akuntansi Untuk Mengikuti Pendidikan Profesi Akuntansi (PPAk). Universitas Islam Negeri Sultan Syarif Kasim Riau.

Aprilianty, E. (2012). Pengaruh kepribadian wirausaha, pengetahuan kewirausahaan, dan lingkungan terhadap minat berwirausaha siswa SMK. Jurnal Pendidikan Vokasi, 2.

Baskara, A. (2018). Pengaruh Motivasi, Kepribadian Dan Lingkungan Terhadap Minat Berwirausaha Mahasiswa Fakultas Keguruan Dan Ilmu Pendidikan Universitas Islam Riau (UIR). Jurnal Pendidikan Ekonomi Akuntansi.

Boz, A., \& Ergeneli, A. (2014). Women Entrepreneurs' Personality Characteristics and Parents' Parenting Style Profile in Turkey. Procedia - Social and Behavioral Sciences, 109, 92-97.

Campbell, C. A. (1992). A decision theory model for entrepreneurial acts. Entrepreneurship Theory and Practice, 17(1), 21-27.

Dewi, A. R. (2018). Pengaruh Motivasi, Biaya, dan Pengetahuan Mahasiswa Tentang UU No. 5 Tahun 2011 Pada Minat PPAk. E-Jurnal Akuntansi Universitas Udayana, 22.

Fahriani, D. (2012). Pengaruh Motivasi terhadap Minat Mahasiswa Akuntansi 
untuk mengikuti Pendidikan Profesi Akuntansi (PPAK). Jurnal Ilmu \& Riset Akuntansi, 1(12), 1-22.

Fradani, A. C. (2016). Pengaruh Dukungan Keluarga, Kecerdasan Adversitas Dan Efikasi Diri Pada Intensi Berwirausaha Siswa SMK Negeri 2 Bojonegoro. Jurnal Pendidikan Edutama, 3.

Herdijono, I., Puspa, Y. H., \& Maulany, G. (2017). The factors affecting entrepreneurship intention. International Journal of Entrpreneurial Knowledge, $5(2)$.

Indarti, N., \& Rostiani, R. (2008). Intensi Kewirausahaan Mahasiswa: Studi Perbandingan Antara Indonesia, Jepang dan Norwegia Intensi Kewirausahaan Mahasiswa : Studi Perbandingan Antara Indonesia , Jepang dan Norwegia. Ekonomika Dan Bisnis Indonesia.

Indriyani, L. (2019). Pengaruh Kepribadian, Pendidikan Kewirausahaan, Dan Lingkungan Keluarga Terhadap Minat Berwirausaha. Economic Education Analysis Journal, 7.

Irfani, H., \& Dahria, M. (2009). Peran Akuntansi Dalam Operasi Bisnis. Saintikom, 2nd.

Jailani, M., \& Sudarma, K. (2017). Pengaruh Kewirausahaan, Motivasi Belajar, Sosial Ekonomi Orang Tua dan Self Efficacy Terhadap Minat Berwirausaha Siswa. Journal of Economic Education, 6(1), 52-59.

Kurniawan, A. R. (2014). Pengaruh Motivasi Karir, Motivasi Ekonomi, dan Motivasi Gelar Terhadap Minat Mahasiswa Akuntansi Mengikuti Pendidikan Profesi Akuntansi (Studi Kasus Pada Mahasiswa Akuntansi Universitas Diponegoro). Universitas Diponegoro.

Kusumastuti, R., \& Waluyo, I. (2013). Pengaruh Motivasi dan Pengetahuan UU No. 5 Tahun 2011 tentang Akuntan Publik terhadap Minat Mahasiswa Akuntansi Mengikuti Pendidikan Profesi Akuntansi (PPAk). Jurnal NOMINAL, 2(2). https:// doi.org/10.21831/nominal.v2i2.1662

Lestari, R. B. (2012). Pengaruh Pendidikan Kewirausahaan terhadap Minat Berwirausaha Mahasiswa di STIE MDP, STMIK MDP, dan STIE MUSI. Forum Bisnis Dan Kewirausahaan Jurnal Ilmiah STIE MDP, 112.

Lubis, I. (2010). Akuntansi Keperilakuan (2nd ed.). Jakarta: Salemba Empat.

Marini, C. K. (2014). Pengaruh self-efficacy, lingkungan keluarga, dan lingkungan sekolah terhadap minat berwirausaha siswa SMK jasa boga. Jurnal Pendidikan Vokasi, 4.

Periera, A., Mashabi, N. A., \& Muhariati, M. (2017). Pengaruh dukungan orangtua terhadap minat anak dalam berwirausaha (pada siswa SMK Strada Koja, Jakarta Utara). Jurnal Kesejahteraan Keluarga Dan Pendidikan, 4.

Rahadian, I. (2008). Pengaruh Motivasi Terhadap Minat Mahasiswa Untuk Mengikuti PPAk. Unika Soegijapranata.

Reeve, J. M., Warren, C. S., \& Duchac, J. E. (2009). Pengantar Akuntansi Adaptasi Indonesia Buku 1. Jakarta: Salemba Empat.

Robbins, S. P., \& Judge, T. A. (2015). Perilaku Organisasi (Organizational Behavior 16th edition). Jakarta: Salemba Empat.

Salindri, W. (2014). Pengaruh Motivasi, Biaya Pendidikan, dan Lama Pendidikan terhadap Minat Mahasiswa untuk mengikuti Pendidikan Profesi Akuntansi (PPAK). Naskah Publikasi Ekonomi Universitas Muhammadiyah Surakarta, 2(4), 
$1-6$.

Shen, T., Osorio, A. E., \& Settles, A. (2017). Does family support matter? The influence of support factors on entrepreneurial attitudes and intentions of college students. Academy of Entrepreneurship Journal, 23.

Suharti. (2011). Faktor-Faktor yang Berpengaruh Terhadap Niat Kewirausahaan (Entrepreneurial Intention) (Studi Terhadap Mahasiswa Universitas Kristen Satya Wacana, Salatiga). Jurnal Manajemen Dan Kewirausahaan.

Trisnawati, N. (2017). Pengaruh Pengetahuan Kewirausahaan Dan Dukungan Sosial Keluarga Pada Minat Berwirausaha Siswa Smk Negeri 1 Pamekasan. Jurnal Ekonomi Pendidikan Dan Kewirausahaan.

Utami, M. A. P., \& Sari, M. M. R. (2017). Pengaruh Motivasi Internal dan Motivasi Eksternal terhadap Minat Berwirausaha Mahasiswa Jurusan Akuntasi Non Reguler. E-Jurnal Akuntasi Universitas Udayana. 